\title{
Recognition of self-assembled water-nitrate cluster in a Co(III)-2,2'-bipyridine host: Synthesis, X-ray structure, DNA cleavage, molecular docking and anticancer activity
}

\author{
SUBRATA DAS ${ }^{\mathrm{a}}$, ANANDAN RANJANI $^{\mathrm{b}}$, LOGANATHAN GAYATHRI $^{\mathrm{b}, \mathrm{c}}$, \\ SUBHASISH SAHA $^{\mathrm{b}, \mathrm{f}}$, JORGE PASAN ${ }^{\mathrm{d}}$, DHARUMADURAI DHANASEKARAN ${ }^{\mathrm{b}}$, \\ MOHAMMAD ABDULKADER AKBARSHA ${ }^{\mathrm{c}}$, MILAN MAJI ${ }^{\mathrm{e}}$ and BHASKAR BISWAS ${ }^{\mathrm{a}, *}$ \\ ${ }^{a}$ Department of Chemistry, Raghunathpur College, Purulia, West Bengal 723 133, India \\ ${ }^{\mathrm{b}}$ Department of Microbiology, Bharathidasan University, Tiruchirappalli, Tamil Nadu 620024 , India \\ ${ }^{\mathrm{c}}$ Mahatma Gandhi-Doerenkamp Center, Bharathidasan University, Tiruchirappalli, Tamil Nadu 620 024, India \\ ${ }^{\mathrm{d}}$ Institut de Ciencia Molecular (ICMol), Universidad de Valencia, Catedrático José Beltrán 2, 46980, Paterna, \\ Valencia, Spain \\ e Department of Chemistry, National Institute of Technology, Mahatma Gandhi Avenue, Durgapur, \\ West Bengal 713 209, India \\ ${ }^{f}$ Present Address: Post Doctoral Fellow, Center for Marine Microbiology, South China Sea Institute of \\ Oceanology, Chinese Academy of Sciences, Guangzhou 510301, China \\ e-mail: mr.bbiswas@rediffmail.com
}

MS received 17 April 2016; revised 15 August 2016; accepted 23 August 2016

\begin{abstract}
A mononuclear cobalt(III) complex $\left[\mathrm{Co}(\text { bpy })_{2} \mathrm{Cl}_{2}\right] \mathrm{NO}_{3} \cdot 2 \mathrm{H}_{2} \mathrm{O}(\mathbf{1})$ (bpy $=2,2^{\prime}$-bipyridine) has been synthesized and crystallographically characterized. Self-assembly of the lattice water molecules from rectangular tetrameric water cluster interacts with nitrate anion along the $c$-axis forming a six membered hexagonal water-nitrate cluster. It presents a new mode of association of water molecules with nitrate molecules which is not predicted theoretically or found experimentally. The molecule effectively cleaves bacterial genomic DNA and shows important cytotoxicity against human hepatocarcinoma cell (HepG2).
\end{abstract}

Keywords. Cobalt(III); Crystal structure; Supramolecular chemistry; Anticancer activity; Molecular docking.

\section{Introduction}

Investigations on structural aspects of water clusters within the lattice of a crystal host have significantly advanced the direction towards the behavior of the bulk water. ${ }^{1,2}$ The diversity of the hydrogen bonding pattern in the water clusters mediated through metal based organic frameworks remain at the focus of attention for a number of decades ${ }^{1-3}$ since water plays an indispensable role in life-sustaining processes for the whole living system. Metallo-organic architectures containing well defined channels extended throughout the crystal lattice can readily access solvent molecules and can play as hosts for water clusters. ${ }^{4-7}$ The non-covalent $\mathrm{O} \cdots \mathrm{O}$ interactions in different water clusters, mixed solvent clusters and anion-water clusters also play a vital role in variable morphological motifs including their theoretical aspects. ${ }^{8-13}$

Transition metal complexes containing polypyridyl ligands have received considerable attraction over a long

\footnotetext{
*For correspondence
}

time for their important photophysical and photochemical properties. ${ }^{14-17}$ Among the transitional metal ions, cobalt is an essential trace element found in cobalamin and a few other metalloproteins. ${ }^{18}$ Cobalamin is necessary for the formation of myelin, an insulating layer found around nerves, supporting the production of red blood cell, for the metabolism of fats and carbohydrates, and in the synthesis of proteins. ${ }^{18}$ Cobalt complexes containing 2,2'-bipyridine have developed several appealing structural and chemical properties in biological system, therapeutic agents and drug design. ${ }^{19,20}$ The detailed investigation of DNA binding and DNA photocleavage studies for cis-dichlorobis(diimine)cobalt(III) chloride complexes (diimine $=\mathrm{N}, \mathrm{N}^{\prime}$-ethylenediamine (en), 2,2'-bipyridine (bpy), 1,10-phenanthroline (phen), 1,10-phenanthroline-5,6-dione (phendione) and dipyrido [3,2-a:2', 3'-c]phenazine (dppz)2,2'-bipyridine) was performed by Joshi et al., in 2006. ${ }^{21}$ Herein, we report the existence of a highly ordered 1D chain of waternitrate clusters in a cobalt(III)-bipyridine crystalline host at room temperature. We believe that the structural motifs in water-nitrate clusters demonstrated herein 
bring to light yet another novel mode of the cooperative association of water molecules with nitrate anions. The molecule effectively cleaves bacterial genomic DNA and shows cytotoxicity against human hepatocarcinoma cell line (HepG2). Molecular modeling suggests that the molecule fits into the groove without disrupting the helical structure of the B-DNA.

\section{Experimental}

\subsection{Materials}

High purity 2,2'-bipyridine (bpy) (Fluka, Germany), ceric ammonium nitrate (CAN) (Aldrich, UK), and $\mathrm{CoCl}_{2} \cdot 6 \mathrm{H}_{2} \mathrm{O}$ (E. Merck, India) were purchased and used as received. All other reagents and solvents were of analytical grade and were purchased from commercial sources and used as received.

\subsection{Synthesis of $\left[\mathrm{Co}(\text { bpy })_{2} \mathrm{Cl}_{2}\right] \mathrm{NO}_{3} \cdot 2 \mathrm{H}_{2} \mathrm{O}(\mathrm{I})$}

2,2'-bipyridine $(0.312 \mathrm{~g}, 2 \mathrm{mmol})$ in $\mathrm{CH}_{3} \mathrm{COOH} / \mathrm{H}_{2} \mathrm{O}$ (10 mL; 6:4, v/v) was added drop by drop to a solution of $\mathrm{CoCl}_{2} \cdot 6 \mathrm{H}_{2} \mathrm{O}(0.237 \mathrm{~g}, 1 \mathrm{mM})$ in the same solvent $(20 \mathrm{~mL})$ followed by the addition of solid CAN $(0.550 \mathrm{~g}, 1 \mathrm{mM})$ in a few portions on a magnetic stirrer for $30 \mathrm{~min}$. The resulting dark brown solution was kept in air for slow evaporation. After 7-10 days, fine microcrystalline product was separated by decantation, washed with n-hexane and dried in vacuo over silica gel indicator. Yield: $0.185 \mathrm{~g}(78.1 \%) .{ }^{1} \mathrm{H}$ NMR $\delta\left(\right.$ DMSO- $\left.d_{6}\right): 7.34(\mathrm{~d}, 1 \mathrm{H}), 7.51(\mathrm{t}, 2 \mathrm{H}), 8.25(\mathrm{t}, 2 \mathrm{H})$, $8.67(\mathrm{t}, 2 \mathrm{H}), 8.78(\mathrm{~d}, 1 \mathrm{H}), 8.96(\mathrm{~d}, 1 \mathrm{H}), 9.80(\mathrm{~d}, 1 \mathrm{H})$ ppm; ${ }^{13} \mathrm{C}$ NMR $\delta\left(\mathrm{DMSO}-d_{6}\right): 125.0,128.90,141.75$, 150.23, 153.47, 157.07, 161.31 ppm. Anal. Calcd. (\%) for $\mathrm{C}_{20} \mathrm{H}_{20} \mathrm{Cl}_{2} \mathrm{CoN}_{5} \mathrm{O}_{5}$ : C 44.46, H 3.73, $\mathrm{N}$ 12.96. Found (\%): C 44.51, H 3.70, N 12.90. Selected IR bands ( $\mathrm{KBr}$ pellet, $\left.\mathrm{cm}^{-1}\right)$ : 3537(w), 3411 (b), 1627(s), 1608(s), 1446(s), 1384(s), 1332(s). UV-Vis ( $\lambda, \mathrm{nm}, 10^{-4} \mathrm{M}, 1 \mathrm{~cm}$ cell length, abs): 303(2.75), 450-700 (0.0055); ESI-MS (MeOH): m/z, 443.0670 (Calcd. 443.0045).

\subsection{Physical measurements}

Infrared spectrum $(\mathrm{KBr})$ was recorded with a FTIR8400S SHIMADZU spectrophotometer in the range $400-3600 \mathrm{~cm}^{-1}$. ${ }^{1} \mathrm{H}$ NMR spectrum in DMSO- $d_{6}$ was obtained on a Bruker Avance $300 \mathrm{MHz}$ spectrometer at $25^{\circ} \mathrm{C}$ and was recorded at $299.948 \mathrm{MHz}$. Ground state absorption was measured with a JASCO V-730 UV-Vis spectrophotometer. Thermal analysis was carried out on a PerkinElmer Diamond TG/DTA system up to $700^{\circ} \mathrm{C}$ in a static nitrogen atmosphere with a heating rate of $10^{\circ} \mathrm{C} / \mathrm{min}$. Elemental analyses were performed on a Perkin Elmer $2400 \mathrm{CHN}$ microanalyser. Electrospray ionization (ESI) mass spectrum was recorded using a Q-tof-micro quadruple mass spectrometer.

\subsection{Crystal structure determination and refinement}

The X-ray data of $\left[\mathrm{Co}(\text { bpy })_{2} \mathrm{Cl}_{2}\right] \mathrm{NO}_{3} \cdot 2 \mathrm{H}_{2} \mathrm{O}$ (1) were collected on a Bruker-Kappa APEX II CCD DUO diffractometer using Mo- $_{\alpha}$ radiation $(\lambda=0.71073 \AA)$ at $293 \mathrm{~K}$. The structure was solved by direct methods, and the structure solution and refinement were based on $|F|^{2}$. All calculations were carried out using the Bruker programs $^{22}$ and SHELXL-97. ${ }^{23}$

\subsection{Electrochemical study}

The cyclic voltammetry experiments were done using usual three-electrode system at $25^{\circ} \mathrm{C}$. A glassy carbon electrode of surface area $0.07065 \mathrm{~cm}^{2}$ was employed as working electrode, a platinum wire acted as the counter electrode and $\mathrm{Ag} / \mathrm{AgCl}$, saturated $\mathrm{KCl}$ was used as the reference electrode. Electrochemical experiments were done using Digi-Ivy Potentiostat (Model DY2312).

\subsection{DNA cleavage studies}

Cleavage of DNA by $\left[\mathrm{Co}(\text { bpy })_{2} \mathrm{Cl}_{2}\right] \mathrm{NO}_{3} \cdot 2 \mathrm{H}_{2} \mathrm{O}(\mathbf{1})$ was monitored by agarose gel electrophoresis technique. The complex $(25,50,75$ and $100 \mu \mathrm{g})$ solutions were incubated with bacterial DNA overnight at $37^{\circ} \mathrm{C}$. After incubation $2 \mu \mathrm{L}$ of bromophenol blue dye was mixed with the sample and loaded carefully into the electrophoresis chamber wells along with the control DNA. TAE buffer was used as a running buffer and finally loaded on agarose gel and passed the constant $50 \mathrm{~V}$ of electricity for $30 \mathrm{~min}$. Then the bands were observed in the gel containing EB under the gel documentation system and photographed to determine the extent of DNA cleavage and the results were compared with the control.

\subsection{Molecular modelling studies}

Twelve base pairs sequence DNA d(ACCGACGTCGGT) 2 (PDB ID: 423D) duplex receptor was selected for molecular docking study. The 3D coordinates of the crystal structure of the DNA duplex receptor structure was downloaded from the Protein Data Bank (http:// www.rcsb.org/pdb/home.do). Before docking, the DNA structure was stimulated and modified following the previously described methods. ${ }^{24}$ The structures of the free ligand and $\left[\mathrm{Co}(\text { bpy })_{2} \mathrm{Cl}_{2}\right] \mathrm{NO}_{3} \cdot 2 \mathrm{H}_{2} \mathrm{O}(\mathbf{1})$ were 
constructed using ChemBioDraw Ultra 12.0. HEX 6.3 was used to setup and perform docking calculations between the metal complex and DNA sequence. The default parameters were used for performing docking.

\subsection{Anticancer activity of the cobalt(III) complex}

2.8.1 Cell culture: The HepG2 human hepatocarcinoma cell was availed from National Center for Cell Science (NCCS), Pune, India. The cells were cultured in 96-well culture plates in DMEM medium (SigmaAldrich, St. Louis, MO, USA), supplemented with $10 \%$ fetal bovine serum (Gibco), $100 \mathrm{U} / \mathrm{mL}$ of penicillin and $100 \mu \mathrm{g} / \mathrm{mL}$ of streptomycin (Gibco), in $\mathrm{CO}_{2}$ incubator (Forma, Thermo Scientific, USA) at $37^{\circ} \mathrm{C}$, in a humidified atmosphere containing $5 \% \mathrm{CO}_{2}$. Cells from passage 15 or less were used in the experiments.

2.8.2 Cytotoxicity assay (MTT assay): The cells were seeded at $5 \times 10^{3}$ cells per well. The culture medium was changed once after $24 \mathrm{~h}$. The complex, dissolved, in minimum quantity of DMSO and diluted with the culture medium to make the concentration in the range 50-500 $\mu \mathrm{M}$ was added to the wells. DMSO solution was used as the solvent control. MTT viability assay using 3-(4,5-di-methylthiazol-2-yl)-2,5-diphenyl$2 \mathrm{H}$-tetrazolium bromide was carried out following a reported literature. ${ }^{25}$ After 24 and $48 \mathrm{~h}$ of treatment, 20 $\mu \mathrm{L}$ of MTT solution [ $5 \mathrm{mg} / \mathrm{mL}$ in phosphate-buffered saline (PBS)] was added to each well. The plate was wrapped with aluminum foil and incubated for $4 \mathrm{~h}$ at $37^{\circ} \mathrm{C}$. The purple formazan product was dissolved in $100 \mu \mathrm{L}$ of DMSO added to each well. The absorbance was read at $570 \mathrm{~nm}$ (measurement) and $630 \mathrm{~nm}$ (reference) for which a 96-well plate reader (Bio-Rad, Hercules, CA, USA) was used. For each experiment three replicates were conducted and used to calculate the mean. From the data thus generated the percentage inhibition was calculated, using the following formula:

$$
\text { Inhibition }(\%)=\left(1-\mathrm{OD}_{\text {untreated }} / \mathrm{OD}_{\text {treated }}\right) \times 100
$$

where $\mathrm{OD}_{\text {untreated }}$ and $\mathrm{OD}_{\text {treated }}$ are Mean OD of untreated cells (control) and Mean OD of treated cells (treated), respectively. The data were plotted on a graph, viability against concentration, and from this graph the $\mathrm{IC}_{50}$ (the concentration at which the complex killed $50 \%$ of the cells) for 24 and $48 \mathrm{~h}$ treatment were determined.

\subsubsection{Acridine orange $(A O)$ and ethidium bromide $(E B)$} staining: To differentiate the viable, apoptotic and necrotic cells acridine orange and ethidium bromide staining was conducted according to Spector et al. ${ }^{26}$ The cell suspension of each sample containing $5 \times$ $10^{5}$ cells, was treated with $25 \mu \mathrm{L}$ of AO and EB solution $(3.8 \mu \mathrm{M}$ of $\mathrm{AO}$ and $2.5 \mu \mathrm{M}$ of $\mathrm{EB}$ in PBS) and examined in a fluorescent microscope (Carl Zeiss, Jena, Germany) using an UV filter (450-490 nm). Three hundred cells per sample were counted in triplicate for each dose point. The cells were scored as viable, apoptotic or necrotic as judged by the staining, nuclear morphology and membrane integrity. ${ }^{26}$ The percentages of apoptotic and necrotic cells were then calculated. Morphological changes were observed and photographed.

2.8.4 Hoechst 33528 Staining: The HePG2 cells were cultured in 6-well plates and treated with $\mathrm{IC}_{50}$ concentration of the complex when DMSO at the same dilution as in the sample was used as control. After $24 \mathrm{~h}$ incubation, the treated and control cells were harvested and stained with Hoechst 33258 (1 mg/mL, aqueous) for $5 \mathrm{~min}$ at room temperature. A drop of cell suspension was placed between a glass slide and a cover slip. At random 300 cells, in triplicate, were observed at $\times 400$ magnification in a fluorescent microscope (Carl Zeiss, Jena) fitted with a $377-355 \mathrm{~nm}$ filter. The percentage of cells reflecting pathological changes was calculated.

\section{Results and Discussion}

\subsection{Synthesis and spectroscopic characterization}

$\left[\mathrm{Co}(\mathrm{bpy})_{2} \mathrm{Cl}_{2}\right] \mathrm{NO}_{3} \cdot 2 \mathrm{H}_{2} \mathrm{O}$ (1) was prepared by slow addition of bpy in an aqueous acetic acid solution to $\mathrm{CoCl}_{2}$ in the same solvent followed by the addition of solid CAN. In this synthesis, CAN was used to oxidize the metal ion at +3 oxidation level, which also supplies nitrate ion to stabilize the cationic part of the complex. The cobalt(III) complex is soluble in all the common solvents like methanol, acetonitrile, water, etc.

The IR spectrum of $\mathbf{1}$ contains characteristic strong peaks for the presence of coordinated bipyridine at 1608 and $1627 \mathrm{~cm}^{-1}$ (Figure S1 in Supplementary Information) while the broad peak centered at $\sim 3411 \mathrm{~cm}^{-1}$ along with two weak peaks at 3537 and $3211 \mathrm{~cm}^{-1}$ indicate the existence of lattice water molecules and water cluster. ${ }^{27} \mathrm{NO}_{3}^{-}$as counter anion in the structure of the complex was detected in the IR spectrum by a sharp band centered at $1384 \mathrm{~cm}^{-1}$.

To investigate the solution stability of the complex, we have performed UV-Vis spectral measurements for a $10^{-4} \mathrm{M}$ methanolic solution of $\mathbf{1}$ at room temperature at various time intervals. The spectral analysis revealed a low intensity and broad transition at $450-650 \mathrm{~nm}$ (Figure S2 in Supplementary Information) attributed to 
ligand field bands in $\mathrm{Co}^{\mathrm{III}}$ octahedral field ${ }^{28}$ and this band remained unaffected over a period of at least 5 days which indicates that the complex is stable in solution at room temperature. ${ }^{28}$ ESI-Mass spectral analysis of the cobalt complex further consolidates this fact by producing molecular ion peak at $\mathrm{m} / \mathrm{z} 443.0670$ (Calc. 443.0045) (Figure S3 in Supplementary Information) in methanol and this experimental peak corresponds to the existence of the cationic species as $\left[\mathrm{Co}(\mathrm{bpy})_{2} \mathrm{Cl}_{2}\right]^{+}$in solution. ${ }^{1} \mathrm{H}$ and ${ }^{13} \mathrm{C}$ NMR spectra (Figures S4 and S5 in Supplementary Information) in DMSO- $d_{6}$ medium also justify the stability of the cation $\left[\mathrm{Co}(\mathrm{bpy})_{2} \mathrm{Cl}_{2}\right]^{+}$ in solution.

\subsection{Crystal structure}

The molecular structure of $\left[\mathrm{Co}(\mathrm{bpy})_{2} \mathrm{Cl}_{2}\right] \mathrm{NO}_{3} \cdot 2 \mathrm{H}_{2} \mathrm{O}$ (1) is shown in Figure 1, while the crystal and structure refinement data are given in the Table 1. Selected bond lengths and angles are listed in Table 2. The bond distance and bond angle values of $\left[\mathrm{Co}(\mathrm{bpy})_{2} \mathrm{Cl}_{2}\right]$ $\mathrm{NO}_{3} \cdot 2 \mathrm{H}_{2} \mathrm{O}$ (1) are quite similar to the previously reported crystal structure, ${ }^{21}\left[\mathrm{Co}(\text { bipy })_{2} \mathrm{Cl}_{2}\right] \mathrm{Cl}$. Though the cationic part of both the complexes is identical, but existence of hetero anions $\left(\mathrm{Cl}^{-}\right.$and $\left.\mathrm{NO}_{3}^{-}\right)$and lattice water molecules in $\mathbf{1}$ enhance the importance of $\mathbf{1}$, principally the formation of water-nitrate cluster in solid state which has drawn special attention to this molecule.
According to the X-ray data, the complex crystallizes in the triclinic system with $P \overline{1}$ space group. The coordination geometry around the $\mathrm{Co}$ (III) centre is best described as a distorted octahedron with a $\mathrm{CoN}_{4} \mathrm{Cl}_{2}$ coordination core formed by four nitrogen atoms of two bidentate bpy ligands and two chlorine atoms (Figure 1). The $\mathrm{Cl}(1)-\mathrm{Co}(1)-\mathrm{Cl}(2)$ angle value $\left(91.53^{\circ}\right.$ ) indicates the cis conformation of the structure. Though there is a possibility to exist in cis- and trans-form of the Co-bpy complex, lower solubility of the cisconformation accounts for the primary isolation of cis- $\left[\mathrm{Co}(\text { bpy })_{2} \mathrm{Cl}_{2}\right] \mathrm{NO}_{3} \cdot 2 \mathrm{H}_{2} \mathrm{O}$ in the form of single crystals. In solid state, adjacent cationic complex units, $\left[\mathrm{Co}(\text { bpy })_{2} \mathrm{Cl}_{2}\right]^{+}$are linked by intermolecular $\mathrm{C}-\mathrm{H} \cdots \mathrm{Cl}$ hydrogen bond and forms a polymeric cationic chain through a number of $\mathrm{C}-\mathrm{H} \cdots \mathrm{Cl}$ intermolecular hydrogen bonds (Figure S6, Table S1 in Supplementary Information). The supramolecular structure of $\left[\mathrm{Co}(\mathrm{bpy})_{2}\right.$ $\left.\mathrm{Cl}_{2}\right] \mathrm{NO}_{3} \cdot 2 \mathrm{H}_{2} \mathrm{O}$ is further stabilized by additional $\mathrm{C}-\mathrm{H} \cdots \pi \quad[\mathrm{C}(10)-\mathrm{H}(10) \cdots \mathrm{Cg}(2), 2.84 \AA$; $\mathrm{C}(20)-$ $\mathrm{H}(20) \cdots \mathrm{Cg}(1), 2.78 \AA$ ] (Figure S7, Table S2 in Supplementary Information).

\subsection{Water cluster and water-nitrate cluster}

The extent of structuring of the water cluster that can be imposed by its environment and vice versa can be important for the design of new metal-organic

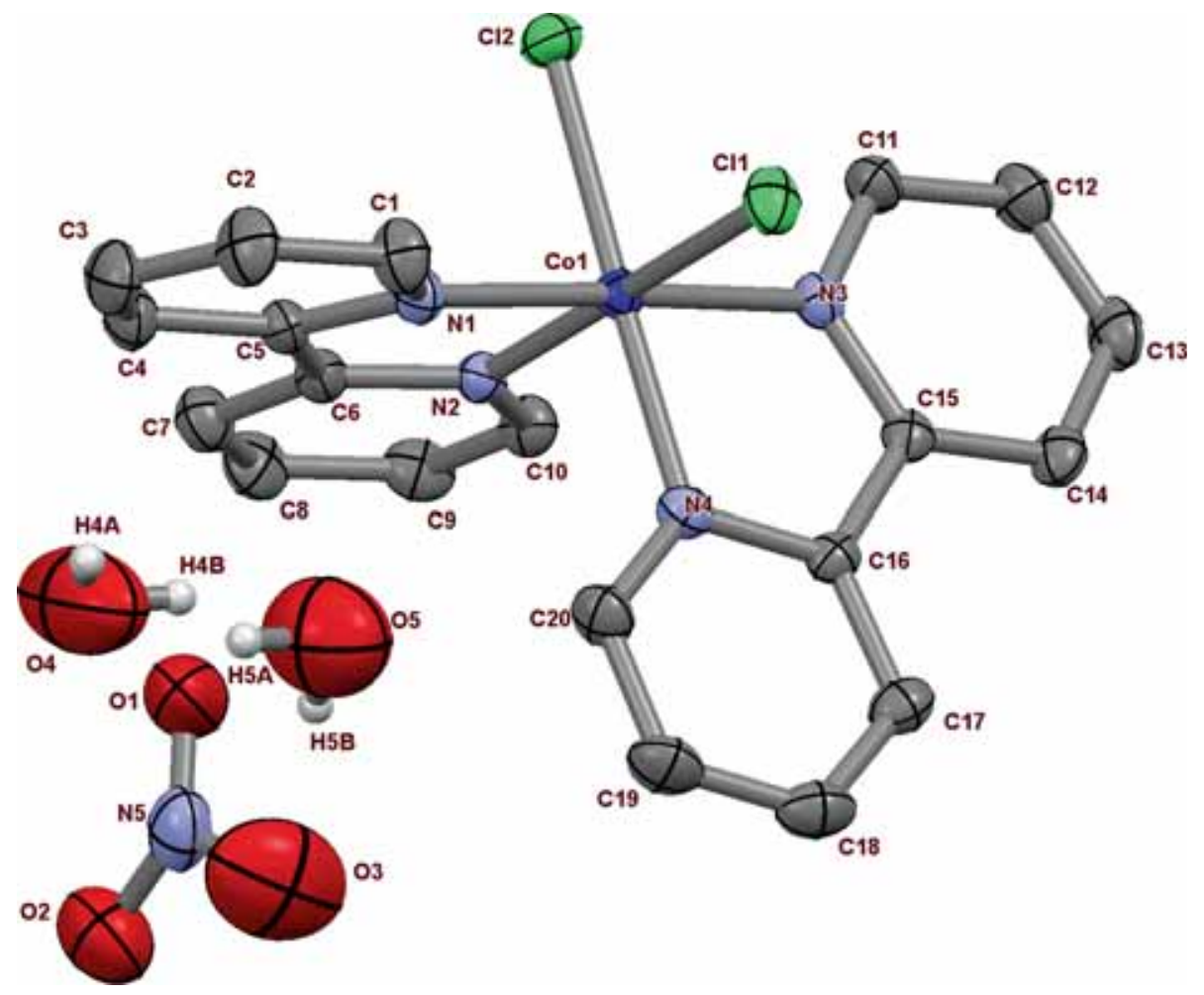

Figure 1. Thermal ellipsoid (30\%) plot of the cation of $\left[\mathrm{Co}(\mathrm{bpy})_{2} \mathrm{Cl}_{2}\right] \mathrm{NO}_{3} \cdot 2 \mathrm{H}_{2} \mathrm{O}$. H-atoms were omitted for clarity. 
Table 1. Crystallographic data of $\left[\mathrm{Co}(\mathrm{bpy})_{2} \mathrm{Cl}_{2}\right] \mathrm{NO}_{3} \cdot 2 \mathrm{H}_{2} \mathrm{O}(\mathbf{1})$.

\begin{tabular}{ll}
\hline Crystal parameters & $\mathbf{1}$ \\
\hline Empirical formula & $\mathrm{C}_{20} \mathrm{H}_{20} \mathrm{CoN}_{5} \mathrm{Cl}_{2} \mathrm{O}_{5}$ \\
Formula weight & 540.24 \\
Temperature & $293 \mathrm{~K}$ \\
Crystal system & Triclinic \\
Space group & $P \overline{1}$ \\
Unit cell dimensions & $\mathrm{a}=7.0995(3) \AA \alpha=91.829(4)^{\circ}$ \\
& $\mathrm{b}=12.2760(6) \AA \AA \AA=91.508(4)^{\circ}$ \\
& $\mathrm{c}=13.1897(7) \AA \gamma=99.633(4)^{\circ}$ \\
Volume & $1132.16(10) \AA^{3}$ \\
$\mathrm{Z}$ & 2 \\
Density (calculated) & $1.585 \mathrm{Mg} / \mathrm{m}^{3}$ \\
Absorption coefficient & $1.037 \mathrm{~mm}^{-1}$ \\
F(000) & 552 \\
Reflections collected & 28913 \\
Independent reflections & 6566 \\
R(int) & 0.051 \\
Goodness-of-fit on $\mathrm{F}^{2}$ & 1.058 \\
$\mathrm{R}$ indices (all data) & $\mathrm{R} 1=0.624, \mathrm{wR} 2=0.1490$ \\
Largest diff. peak and hole & 0.56 and $-0.45 \mathrm{e} . \AA^{-3}$ \\
\hline
\end{tabular}

Table 2. Selected bond lengths $(\AA)$ and bond angles $\left({ }^{\circ}\right)$ for $\left[\mathrm{Co}(\mathrm{bpy})_{2} \mathrm{Cl}_{2}\right] \mathrm{NO}_{3} \cdot 2 \mathrm{H}_{2} \mathrm{O}$.

\begin{tabular}{lccccc}
\hline Bond lengths & & & & & \\
Co(1)-N(1) & $1.938(3)$ & $\mathrm{Co}(1)-\mathrm{N}(3)$ & $1.938(3)$ & $\mathrm{Co}(1)-\mathrm{Cl}(1)$ & $2.2346(10)$ \\
$\mathrm{Co}(1)-\mathrm{N}(2)$ & $1.934(3)$ & $\mathrm{Co}(1)-\mathrm{N}(4)$ & $1.944(3)$ & $\mathrm{Co}(1)-\mathrm{Cl}(2)$ & $2.2399(11)$ \\
Bond angles & & & & \\
$\mathrm{Cl}(1)-\mathrm{Co}(1)-\mathrm{Cl}(2)$ & $91.53(4)$ & $\mathrm{Cl}(1)-\mathrm{Co}(1)-\mathrm{N}(1)$ & $87.12(8)$ & $\mathrm{Cl}(1)-\mathrm{Co}(1)-\mathrm{N}(2)$ & $88.27(8)$ \\
$\mathrm{Cl}(1)-\mathrm{Co}(1)-\mathrm{N}(3)$ & $94.96(8)$ & $\mathrm{Cl}(1)-\mathrm{Co}(1)-\mathrm{N}(4)$ & $177.81(8)$ & $\mathrm{Cl}(2)-\mathrm{Co}(1)-\mathrm{N}(1)$ & $95.36(8)$ \\
$\mathrm{Cl}(2)-\mathrm{Co}(1)-\mathrm{N}(2)$ & $178.27(9)$ & $\mathrm{Cl}(2)-\mathrm{Co}(1)-\mathrm{N}(3)$ & $86.22(8)$ & $\mathrm{Cl}(2)-\mathrm{Co}(1)-\mathrm{N}(4)$ & $89.05(8)$ \\
$\mathrm{N}(1)-\mathrm{Co}(1)-\mathrm{N}(2)$ & $82.92(11)$ & $\mathrm{N}(1)-\mathrm{Co}(1)-\mathrm{N}(3)$ & $177.36(12)$ & $\mathrm{N}(1)-\mathrm{Co}(1)-\mathrm{N}(4)$ & $94.94(11)$ \\
$\mathrm{N}(2)-\mathrm{Co}(1)-\mathrm{N}(3)$ & $95.50(11)$ & $\mathrm{N}(2)-\mathrm{Co}(1)-\mathrm{N}(4)$ & $91.22(11)$ & $\mathrm{N}(3)-\mathrm{Co}(1)-\mathrm{N}(4)$ & $82.97(11)$ \\
\hline
\end{tabular}

framework structures. ${ }^{3}$ The vibrational stretching frequencies of the $\mathrm{O}-\mathrm{H}$ bonds corresponding to the water cluster have been principally characterized by FTIR spectroscopic analysis of $\mathbf{1}$. A weak peak appears at $3537 \mathrm{~cm}^{-1}$ in the spectrum followed by a broad band centered around $3411 \mathrm{~cm}^{-1}$ and a weak broad band at $3231 \mathrm{~cm}^{-1}$ (Figure S1). P K Bharadwaj et al., showed the existence of $\left(\mathrm{H}_{2} \mathrm{O}\right)_{12}$ core structure through the assignment of $\mathrm{O}-\mathrm{H}$ stretching frequencies in the IR spectrum at 3635 and $3410 \mathrm{~cm}^{-1}$. ${ }^{\mathrm{c}}$ In comparison, the vibration of $\mathrm{O}-\mathrm{H}$ bond in the planar hexamers in ice I and II phases occur ${ }^{2 \mathrm{a}}$ at $3220 \mathrm{~cm}^{-1}$. In our case, the difference in the stretching vibration with the reported literature arises from its different environment.

Analysis of the crystal packing of $\left[\mathrm{Co}(\mathrm{bpy})_{2} \mathrm{Cl}_{2}\right]$ $\mathrm{NO}_{3} \cdot 2 \mathrm{H}_{2} \mathrm{O}$ reveals that layers of the $\left[\mathrm{Co}(\mathrm{bpy})_{2} \mathrm{Cl}_{2}\right]^{+}$ cations are separated by the layers of water and waternitrate clusters (Figure S8 in Supplementary Information). This feature of the complex drew our attention since polypyridyl moieties that are present in biological molecules might stabilize various water topologies in the environment, resembling those in living systems. ${ }^{3 e}$ The crystal packing diagram shows that the water and water-nitrate clusters in the cationic net are stacked one on top of the other along the crystallographic $c$-axis, and are associated with neighboring metal complex through the $\mathrm{C}-\mathrm{H} \cdots \mathrm{O}$ hydrogen bonding interactions (Table S1 in Supplementary Information). The hydrogen bonding association leads to the formation of cyclic water tetramers and hexagonal water-nitrate clusters (Figure 2, Table S1). The tetrameric water clusters are bridged by two nitrate molecules, leading to a 1D infinite chain supported by cationic metal complex (Figure 3). This new 1D water and water-nitrate morphology consists of fused cyclic rectangular fourand cyclic hexagonal six-membered rings. The oxygen atoms, which are involved in the formation of the cyclic water tetramer, lie with the $\mathrm{OH}$... O bond distances (H4B ‥ O5, H5B . . O4) of 1.91, $1.93 \AA$, and $\angle \mathrm{O} 5 \cdots \mathrm{H} 4 \mathrm{~B} \cdots \mathrm{O} 5$ of $103.9^{\circ}$ and $\angle \mathrm{H} 4 \mathrm{~B} \cdots \mathrm{O} 5 \cdots \mathrm{H} 4 \mathrm{~B}$ 


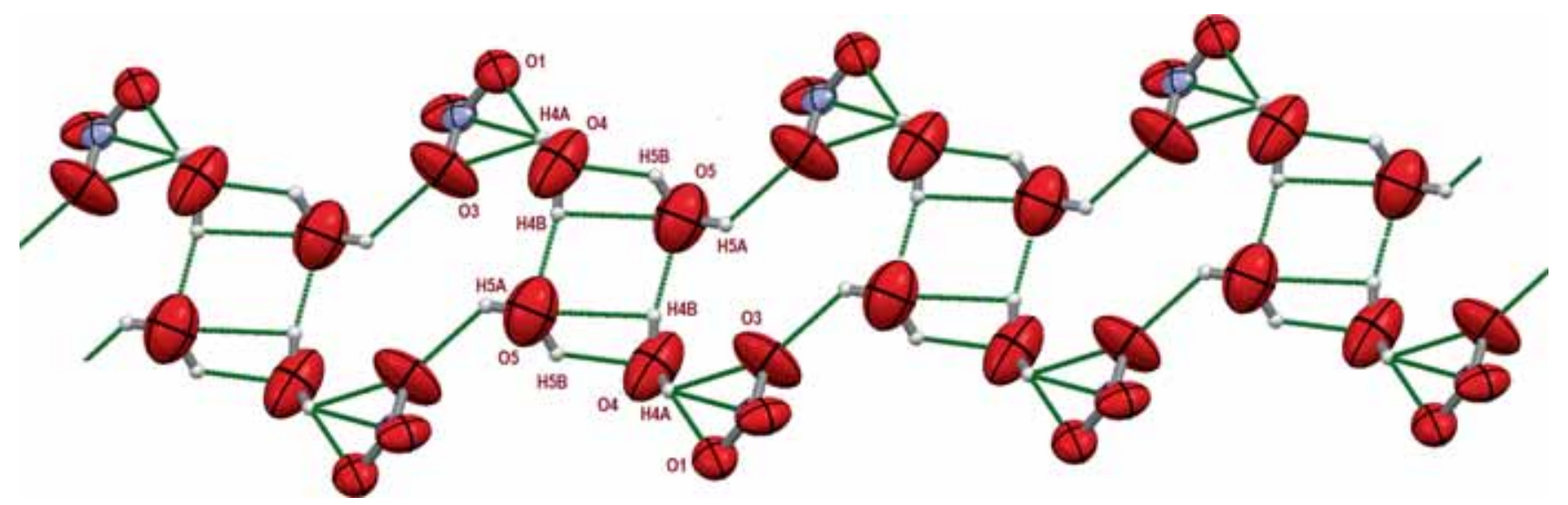

Figure 2. Formation of $1 \mathrm{D}$ anionic chain through intermolecular hydrogen bonds of the $\left[\left(\mathrm{NO}_{3}\right)_{2}\left(\mathrm{H}_{2} \mathrm{O}\right)_{4}\right]^{2-}$ clusters, in the structure of $\left[\mathrm{Co}(\mathrm{bpy})_{2} \mathrm{Cl}_{2}\right] \mathrm{NO}_{3} \cdot 2 \mathrm{H}_{2} \mathrm{O}$.

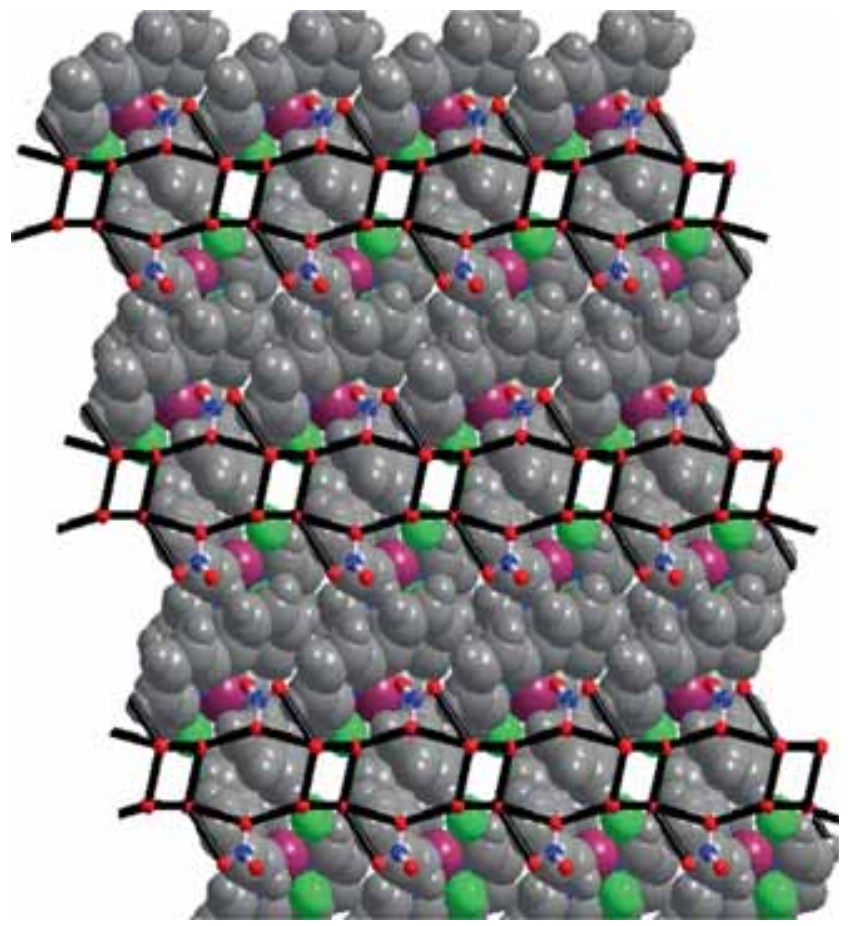

Figure 3. Hydrogen-bonded network of the water molecules and water-nitrate clusters in the metal-organic layer (space-filling) and water-nitrate network (ball-and-stick) in $\left[\mathrm{Co}(\text { bpy })_{2} \mathrm{Cl}_{2}\right] \mathrm{NO}_{3} \cdot 2 \mathrm{H}_{2} \mathrm{O}$.

of $76.0^{\circ}$ (Table $\mathrm{S} 1$ in Supplementary Information). The $\mathrm{OH} \cdots \mathrm{O}$ bond distances between the water and nitrate oxygen atoms, involved in the bridging waternitrate cluster, are 2.05 and $2.35 \AA$, while the $\angle \mathrm{O} 3 \cdots \mathrm{H} 4 \mathrm{~A} \cdots \mathrm{O} 4, \angle \mathrm{O} 4 \cdots \mathrm{H} 4 \mathrm{~B} \cdots \mathrm{O} 5$ and $\angle \mathrm{O} 5 \cdots$ $\mathrm{H} 5 \mathrm{~A} \cdots \mathrm{O} 3$ within the same water-nitrate six-membered cluster, are 126.4, 163.59 and 133.2 ${ }^{\circ}$. Furthermore, the nitrate anions serve as linkers in the tetrameric cationic aggregates, formed through intermolecular hydrogen bonds of two dimeric cationic building blocks of $\left[\mathrm{Co}(\mathrm{bpy})_{2} \mathrm{Cl}_{2}\right]^{+}$and two nitrate anions (Figure S6, Table S1 in Supplementary Information).

\subsection{Thermogravimetric analysis}

The thermal properties of $\mathbf{1}$ in nitrogen atmosphere were studied by TG analysis in order to determine its stability (Figure S9 in Supplementary Information). The complex is decomposed in four clearly defined steps with the final residue corresponding to cobalt. The first step corresponds to the loss of two water molecules at $\sim 93^{\circ} \mathrm{C}$ (Figure S9) while in the second step at $\sim 300^{\circ} \mathrm{C}$, anionic nitrate ion decomposes. In the third step, the labile chloride ion coordinated to cobalt ion decomposes and finally the main architecture around metal coordination is lost. Thus, the TG analysis data supports the presence of two solvent molecules in the structure of $\left[\mathrm{Co}(\mathrm{bpy})_{2} \mathrm{Cl}_{2}\right] \mathrm{NO}_{3} \cdot 2 \mathrm{H}_{2} \mathrm{O}(\mathbf{1})$.

\subsection{Electrochemical study}

The electrochemical behavior of the complex was studied by using cyclic voltammetry. The cyclic voltammogram (Figure S10 in Supplementary Information) of $\mathbf{1}$ in DMSO in the presence of tetrabutyl ammonium bromide showed that it undergoes three irreversible reductions at $-0.785,-1.235$ and $-1.655 \mathrm{~V}$ vs. $\mathrm{Ag} / \mathrm{AgCl}$ saturated $\mathrm{KCl}$, respectively.

\subsection{DNA cleavage activity}

Incubation of $\left[\mathrm{Co}(\mathrm{bpy})_{2} \mathrm{Cl}_{2}\right] \mathrm{NO}_{3} \cdot 2 \mathrm{H}_{2} \mathrm{O} \mathrm{I}$ with the bacterial genomic DNA resulted in its cleavage (Figure 4). With increasing concentrations of the complex $(25,50$, 75 and $100 \mu \mathrm{g} / \mathrm{mL}$ ) the extent of cleavage of the bacterial genomic DNA was also increased with the changes 


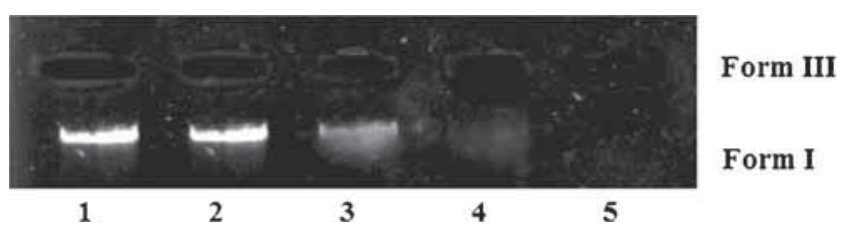

Figure 4. Concentration dependent cleavage of the bacterial genomic DNA by $\left[\mathrm{Co}(\text { bpy })_{2} \mathrm{Cl}_{2}\right] \mathrm{NO}_{3} \cdot 2 \mathrm{H}_{2} \mathrm{O}$. Lane 1 shows the control DNA. lane 2, DNA + sample (25 $\mu \mathrm{g})$; lane 3, DNA+ sample (50 $\mu \mathrm{g})$; lane 4, DNA+sample (75 $\mu \mathrm{g})$; lane 5, DNA+sample $(100 \mu \mathrm{g})$.

in the band size and at the highest concentration (100 $\mu \mathrm{g} / \mathrm{mL}$ ) complete disappearance of the band (Form I) with the appearance of linear form (Form III).

\subsection{Modelling of cobalt(III) complex (1) with the dodecamer d(ACCGACGTCGGT $)_{2}$}

Molecular modelling studies on the three modes of interaction of $\left[\mathrm{Co}(\text { bpy })_{2} \mathrm{Cl}_{2}\right] \mathrm{NO}_{3} \cdot 2 \mathrm{H}_{2} \mathrm{O}$ with DNA have been performed by placing the complex in the major groove, minor groove of the duplex DNA and the central part of the dodecamer. The output binding energy value of 1 was $-304.0 \mathrm{kcal} / \mathrm{mol}$. According to this docking experiment and energy values obtained from the docking, 1 was found to strongly interact

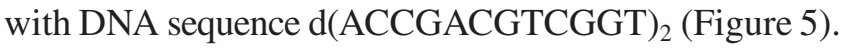
The decrease of the energy value for the $\left[\mathrm{Co}(\mathrm{bpy})_{2} \mathrm{Cl}_{2}\right]$ $\mathrm{NO}_{3} \cdot 2 \mathrm{H}_{2} \mathrm{O}$-DNA association is due to substantial H-bond formation between the metal complex and DNA leading to internal binding (Figure 5).

\subsection{Anticancer activity of the cobalt(III) complex}

3.8.1 MTT Assay: The cytotoxicity of the complex was examined against HepG2 cell by adopting MTT assay. The $\mathrm{IC}_{50}$ values revealed that cobalt(III) complex exhibited effective cytotoxicity for both 24 and $48 \mathrm{~h}$ treatment periods in a dose-dependent manner. The $\mathrm{IC}_{50}$ value at $48 \mathrm{~h}(210.0 \pm 0.2 \mu \mathrm{g} / \mathrm{mL})$ was lower than that at $24 \mathrm{~h}(230.0 \pm 0.1 \mu \mathrm{g} / \mathrm{mL})$, clearly indicating that the cytotoxic effect is time dependent.

3.8.2 AO/EB staining: In general, in this AO/EB staining method, the fluorescence pattern of the stain depends on the viability and membrane integrity of the cells. Dead cells are stained by ethidium bromide and fluoresce orange-red, whereas live cells are permeable to acridine orange only and thus fluoresce green. Figure 6 indicates the apoptotic (early apoptotic cells

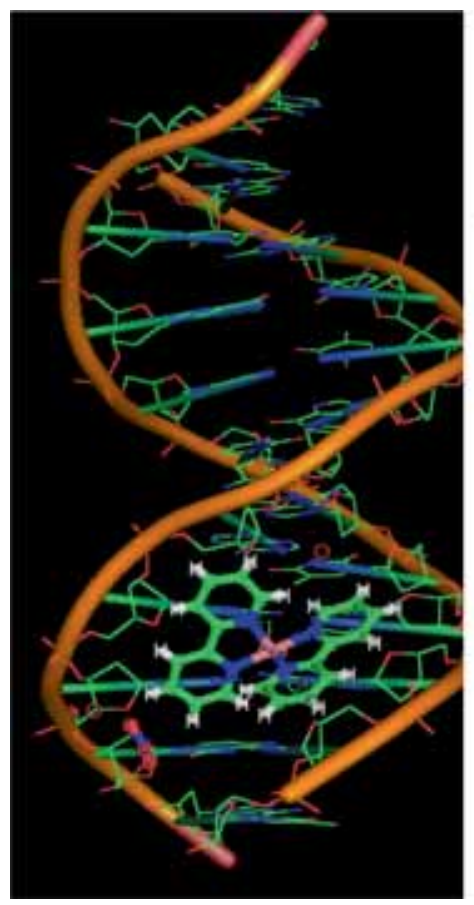

In silico interaction between cobalt(III)-bipyridyl and DNA

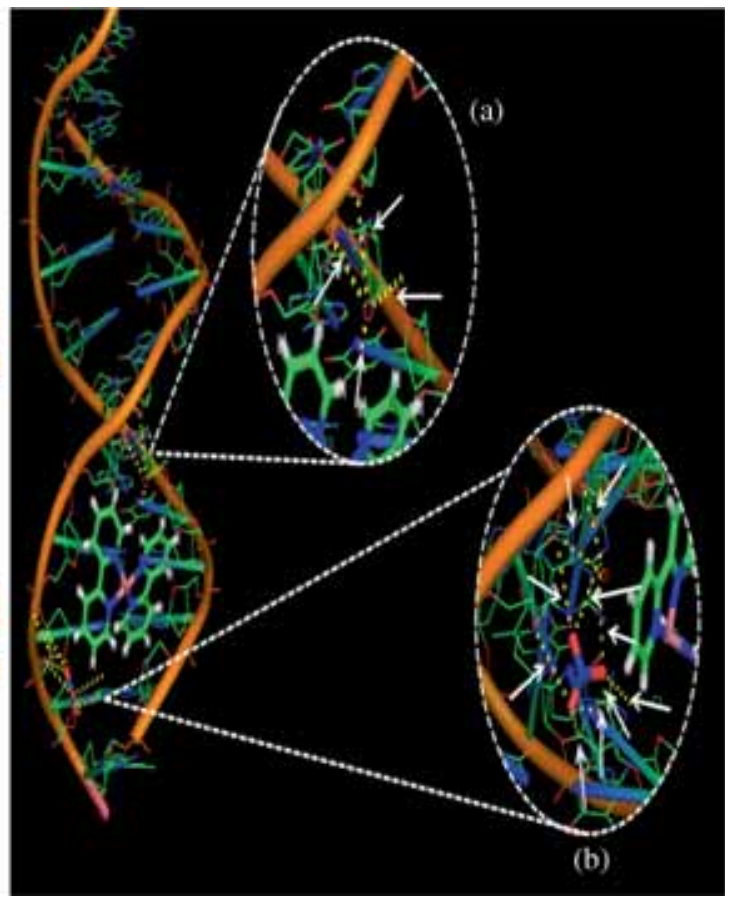

Total $14 \mathrm{H}$ bonds were observed during the interaction between cobalt(III)-bipyridyl and DNA (a) 4 H-bonds with oxygen atom of water molecule (b) another $4 \mathrm{H}$-bonds with oxygen atom of $\mathrm{H}_{2} \mathrm{O}$ and $6 \mathrm{H}$-bonds with nitrogen atom

Figure 5. Minor groove interaction by $\left[\mathrm{Co}(\mathrm{bpy})_{2} \mathrm{Cl}_{2}\right] \mathrm{NO}_{3} \cdot 2 \mathrm{H}_{2} \mathrm{O}$ with DNA duplex through $\mathrm{H}$-bonding interaction. 
which show nuclear condensation emit orange-green fluorescence; late apoptotic cells with highly condensed or fragmented chromatin fluoresce orange to red) and necrotic (fluoresce orange to red with no indication of chromatin fragmentation) morphologies induced by the cobalt complex at its $\mathrm{IC}_{50}$ concentration. Figure 7 shows the efficacy of the complex treated for $24 \mathrm{~h}$ to induce

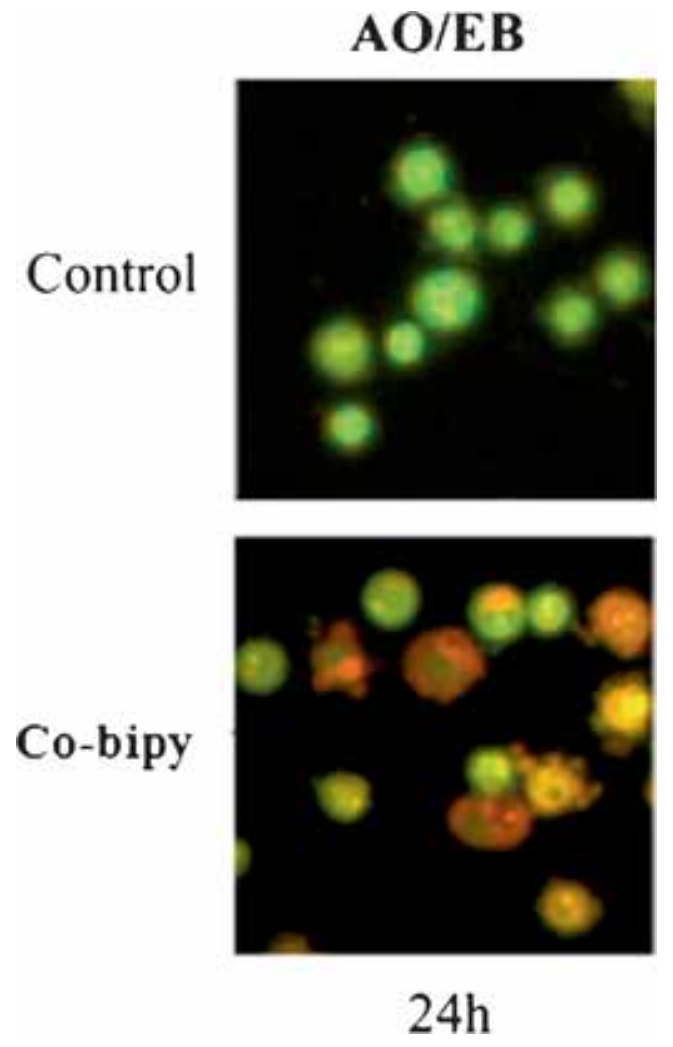

Figure 6. Representative morphological changes produced in $\mathrm{HepG} 2$ cells by $\left[\mathrm{Co}(\mathrm{bpy})_{2} \mathrm{Cl}_{2}\right] \mathrm{NO}_{3} \cdot 2 \mathrm{H}_{2} \mathrm{O}(\mathbf{1})$ as revealed in $\mathrm{AO} / \mathrm{EB}$ staining after $24 \mathrm{~h}$ incubation.

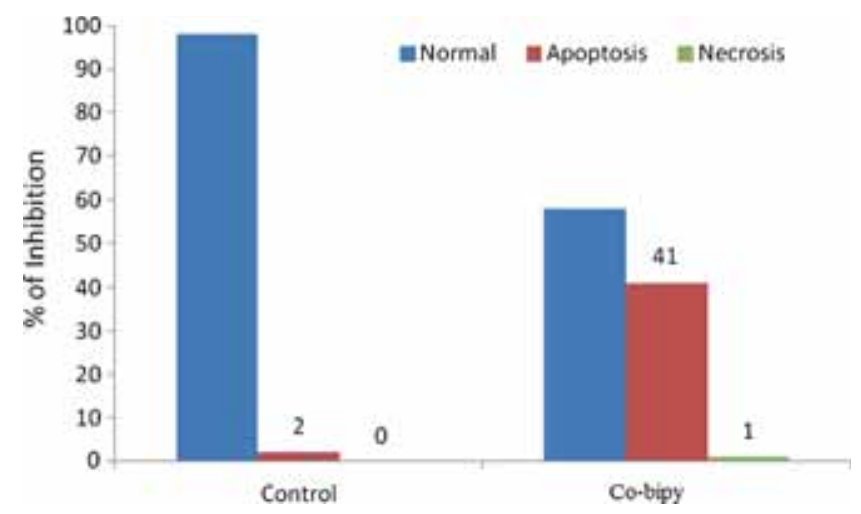

Figure 7. The effect of $\left[\mathrm{Co}(\mathrm{bpy})_{2} \mathrm{Cl}_{2}\right] \mathrm{NO}_{3} \cdot 2 \mathrm{H}_{2} \mathrm{O}$ (1) on HepG2 cell as revealed in acridine orange and ethidium bromide staining. Relative percentage of morphological changes was determined and classified into three categories: viable, apoptosis and necrosis as compared with the control cells after $24 \mathrm{~h}$ incubation. apoptotic (41\%) and necrotic (1\%) cell death compared to controls. All these morphological changes reflected the effective anti-tumor properties of the cobalt(III)bipy complex.

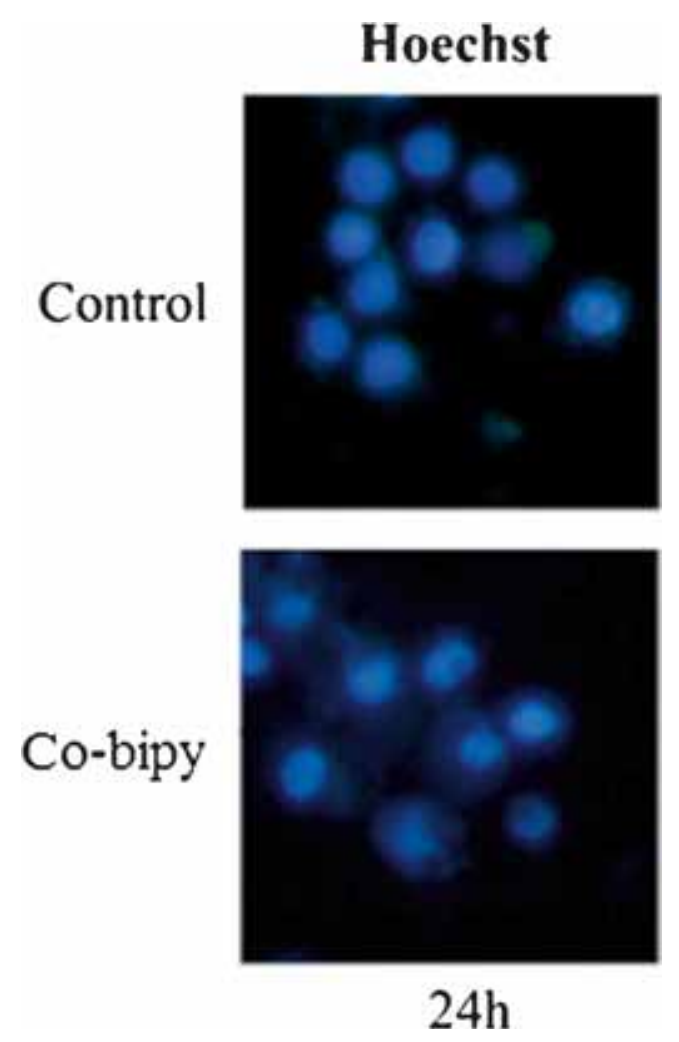

Figure 8. Representative morphological changes observed for $\left[\mathrm{Co}(\text { bpy })_{2} \mathrm{Cl}_{2}\right] \mathrm{NO}_{3} \cdot 2 \mathrm{H}_{2} \mathrm{O}$ (1) by Hoechst 33258 staining against HepG2 human hepatocarcinoma cell at $24 \mathrm{~h}$ incubation.

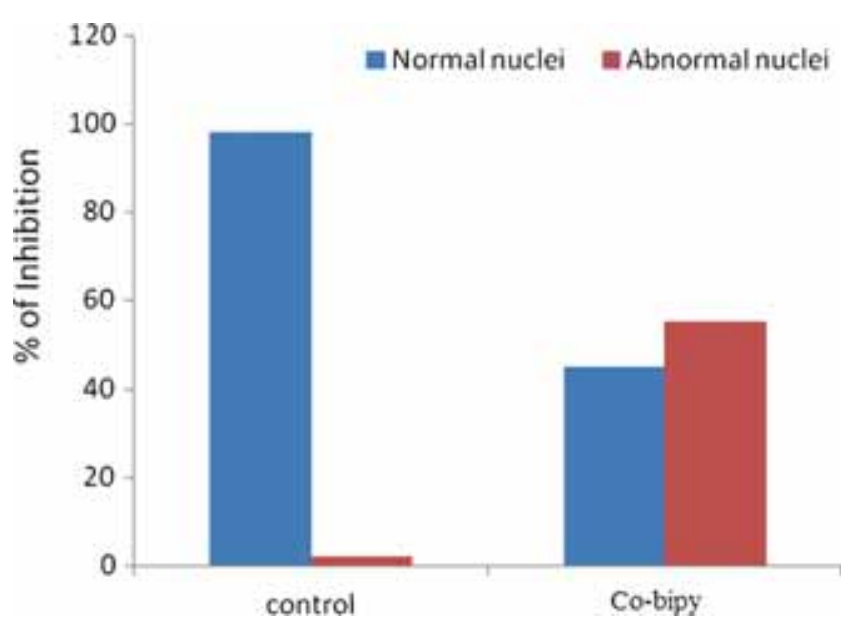

Figure 9. The effect of $\left[\mathrm{Co}(\mathrm{bpy})_{2} \mathrm{Cl}_{2}\right] \mathrm{NO}_{3} \cdot 2 \mathrm{H}_{2} \mathrm{O}$ (1) on HepG2 cell as revealed in Hoechst staining. Relative percentage of morphological changes was determined and classified into two categories: normal and abnormal nuclei as compared with the control cells after $24 \mathrm{~h}$ incubation. 
3.8.3 Hoechst Staining: Morphological changes in the nucleus and chromatin were revealed by Hoechst 33528 staining method. The cells treated for $24 \mathrm{~h}$ at $\mathrm{IC}_{50}$ concentration of cobalt(III)-bipy showed changes in the morphology of their nuclei as compared to the nuclei of control cells. In the control cells, the nuclei were spherical with intact chromatin while after treatment with the complex for $24 \mathrm{~h}$, changes were observed such as chromatin marginalization, condensation and fragmentation. Figure 8 indicates the apoptotic nuclear morphology induced by the complex at $\mathrm{IC}_{50}$ concentration and Figure 9 reveals that $55 \%$ of treated cells showed abnormal nuclei compared to control cells.

\section{Conclusions}

In summary, we have characterized a highly ordered 1D water-nitrate cluster in the cobalt(III)-2,2'-bipyridine $\left(\left[\mathrm{Co}(\text { bpy })_{2} \mathrm{Cl}_{2}\right] \mathrm{NO}_{3} \cdot 2 \mathrm{H}_{2} \mathrm{O}\right)$ molecular host. This particular structural motif in water-nitrate clusters demonstrated herein may bring to light yet another novel mode of the cooperative association of water molecules with nitrate anions. It brings about efficient cleavage of double-stranded DNA without the requirement of an external agent in a concentration dependent manner. The cobalt(III) complex also exhibits good anticancer activity against human hepatocarcinoma cell (HepG2) in terms of attacking the DNA in cancer cells. Molecular modelling studies suggest that the cobalt(III) complex strongly interacts with DNA sequence d(ACCGACGTCGGT) $)_{2}$ through substantial $\mathrm{H}$-bonding interaction and sits at groove position.

\section{Supplementary Information (SI)}

Supplementary crystallographic data are available free of charge from The Director, CCDC, 12 Union Road, Cambridge, CB2 1EZ, UK (fax: +44-1223-336033; E-mail: deposit@ccdc.cam.ac.uk or www: http://www. ccdc.cam.ac.uk) upon request, quoting deposition number CCDC 825244. FTIR, UV-Vis spectra, ESI-MS, supramolecular interactions, TGA diagram and table of hydrogen bonded parameters (Figures S1-S10 and Tables S1 and S2) are given in Supplementary Information, available at www.ias.ac.in/chemsci.

\section{Acknowledgements}

DD thanks the Science \& Engineering Research Board (SERB), New Delhi for fellowship to him. The work is supported financially by SERB, India under the FAST TRACK SCHEME for YOUNG SCIENTIST (No. SB/FT/CS-088/2013 dtd. 21/05/2014). BB sincerely thanks Dr. P. S. Guin and Dr. S. Roy, Department of Chemistry, Shibpur Dinobundhoo Institute (College), Howrah 711102, West Bengal for the electrochemical data of the cobalt(III) complex.

\section{References}

1. (a) Ludwig R 2001 Angew. Chem. Int. Ed. Engl. 40 1808; (b) Soper A K 2002 Science 297 1288; (c) Ghosh S K and Bharadwaj P K 2004 Angew. Chem. Int. Ed. Engl. 43 3577; (d) Lakshminarayan P S, Suresh E and Ghosh P 2005 J. Am. Chem. Soc. 127 13132; (e) Dey D, Pal S, Yadav H R, Sengupta P S, Choudhury A R, Kole N and Biswas B 2015 RSC Adv. 542681

2. (a) Eisenberg D and Kauzmann W 1969 In The Structure and Properties of Water (New York: Oxford University Press); (b) Liu K, Cruzan J D and Saykally R J 1996 Science 271929

3. (a) Fletcher N H 1970 In The Chemical Physics of Ice (Cambridge: Cambridge University Press); (b) Koza M, Schober H, TJlle A, Fujara J and Hansen T 1999 Nature 397 660; (c) Keutsch F N and Saykally R J 2001 Proc. Natl. Acad. Sci. U.S.A. 98 10533; (d) Ball P $1999 \mathrm{In} \mathrm{H}_{2} \mathrm{O}$ : A Biography of Water (London: Weidenfeld \& Nicolson); (e) E Westhoff (Ed.) 1993 Water and Biological Macromolecules (Boca Raton, FL: CRC Press)

4. (a) Raghuraman K, Katti K K, Barbour L J, Pillarsetty N, Barnes C L and Katti K V 2003 J. Am. Chem. Soc. 125 6955; (b) Biswas B, Al-Hunaiti A, Räisänen M T, Ansalone S, Leskelä M, Repo T, Chen Y -T, Tsai H -L, Naik A D, Railliet A P, Garcia Y, Ghosh R and Kole N 2012 Eur. J. Inorg. Chem. 4479

5. Liu L-L, Ren Z-G, Wan L-M, Ding H-Y and Lang J-P 2011 Cryst. Eng. Commun. 135718

6. Wang X-B, Yang X and Wang L-S 2002 J. Chem. Phys. 116561

7. Xiao F, Lü J, Guo Z, Li T, Li Y and Cao R 2008 Inorg. Chem. Commun. 11105

8. Wu Y-P, Fu F, Li D-S, Yang Z-H, Zou K and Wang Y-Y 2008 Inorg. Chem. Commun. 11621

9. Fabelo O, Pasán J, Delgado L C, Delgado F S, Labrador A, Lloret F, Julve M and Ruiz-Pérez C 2008 Cryst. Eng. Commun. 101743

10. Bai S -Q, Quek G Y H, Koh L L and Hor T S A 2010 Cryst. Eng. Commun. 12226

11. (a) Lillehaug J R and Kleppe K 1975 Biochem 14 1225; (b) Minero C, Mariella G, Maurino V and Pelizzetti E 2000 Langmuir 162632

12. Hu T, Zhao X, Hu X, Xu Y and Sun D S D 2011 RSC Adv. 11682

13. (a) Li Y, Jiang L, Feng X-L and Lu T-B 2008 Cryst. Growth Des. 8 3689; (b) Liu D, Li H-X, Ren Z -G, Chen Y, Zhang Y and Lang J -P 2009 Cryst. Growth Des. 94562

14. (a) Reichmann M E, Rice S A, Thomas C A and Doty P 1954 J. Am. Chem. Soc. 76 3047; (b) Kumar S C, Pal A, Mitra M, Manikandamathavan V M, Lin C H, Nair B U and Ghosh R 2015 J. Chem. Sci. 1271375

15. (a) Dey D, Kaur G, Ranjani A, Gyathri L, Chakraborty P, Adhikary J, Pasan J, Dhanasekaran D, Choudhury A R, Akbarsha M A, Kole N and Biswas B 2014 Eur. J. Inorg. Chem. 3350; (b) Lahiri D, Majumdar R, Patra A K and Chakravarty A R 2010 J. Chem. Sci. 122321 
16. (a) Dey D, De A, Pal S, Mitra P, Ranjani A, Gayathri L, Chandraleka S, Dhanasekaran D, Akbarsha M A, Kole $\mathrm{N}$ and Biswas B 2015 Ind. J. Chem. A 54 170; (b) Dey D, Das S, Yadav H R, Ranjani A, Gyathri L, Roy S, Guin P S, Dhanasekaran D, Choudhury A R, Akbarsh M A and Biswas B 2016 Polyhedron 106106

17. (a) Abhijit P, Biswas B, Mitra M, Rajalakshmi S, Purohit C S, Hazra S, Kumar G S, Nair B U and Ghosh R 2013 J. Chem. Sci. 125 1161; (b) Biswas B, Patra M, Dutta S, Ganguly M and Kole N 2013 J. Chem. Sci. 1251445

18. (a) Trawick B N, Daniher A T and Bashkin J K 1988 Chem. Rev. 98 939; (b) Kumar R S, Sasikala K and Arunachalam S 2007 J. Chem. Sci. 119231

19. (a) Sammes P G and Yahioglu G 1994 Chem. Soc. Rev. 23 327; (b) Reddy P R and Manjula P 2007 J. Chem. Sci. 119603

20. (a) Arounaguiri S, Easwaramoorthy D, Ashokkumar A, Dattagupta A and Maiya B G $2000 \mathrm{~J}$. Chem. Sci. 112 1; (b) Dey D, Basu Roy A, Shen C-Y, Tsai H-L, Ranjani A, Gayathri L, Chandraleka S, Dhanasekaran D, Akbarsha M A, Kole N and Biswas B 2015 J. Chem. Sci. 127649
21. Ghosh S, Barve A C, Kumbhar A A, Kumbhar A S, Puranik V G, Datar P A, Sonawane U B and Joshi R R 2006 J. Inorg. Biochem. 100331

22. SHELXTL 5.10, 1997 (Bruker Analytical X-ray Instruments Inc.: Karlsruche, Germany)

23. Farrugia L J 1997 J. Appl. Crystallogr. 30565

24. Ramesh G N, Rao Y S, Prathima B, Sravani V and Reddy A V 2012 Der Pharmacia Lettre 41299

25. Mosmann T 1983 J. Immunol. Methods 6555

26. Spector D L, Goldman R D and Leinwand L A 1998 In Cell: A Laboratory Manual Culture and Biochemical Analysis of Cells Vol. 1 (New York: Cold Spring Harbor Laboratory Press) p. 34.1-34.9

27. (a) Nakamoto K 1997 In Infrared and Raman Spectra of Inorganic and Coordination Compounds Part B: Applications in Coordination, Organometallic and Bioinorganic Chemistry (New York: John Wiley) p.116; (b) Barbara S 2004 In Infrared Spectroscopy: Fundamentals and Applications (Wiley: New York); (c) Rao C N R, Sampathkumaran E V, Nagarajan R, Paul G, Behra J N and Choudhury A 2004 Chem. Mater. 161441

28. Sole J G, Bausa L E and Jaque D 2005 In An Introduction to Optical Spectroscopy of Inorganic solids (New York: John Wiley) 